\title{
Abnormalities of B-cell activation and immunoregulation in patients with Crohn's disease
}

\author{
G SIEBER, F HERRMANN, M ZEITZ, H TEICHMANN, AND H RÜHL \\ From the Department of Haematology and Department of Gastroenterology, Medizinische Klinik, Klinikum \\ Steglitz der Freien Universität Berlin, Berlin
}

SUMmaRY We have studied B-lymphocyte function in 39 patients with Crohn's disease and 35 normal individuals using a reverse haemolytic plaque assay as the effector system. Ten patients had active Crohn's disease, the others being in an inactive state of the disease. Compared with normal individuals, the Crohn's disease patients - especially those in the active state of the disease - had markedly raised numbers of spontaneous immunoglobulin secreting cells and severely decreased responses to the polyclonal activator pokeweed mitogen. The differences between the reactivity of patients with active disease and those with inactive disease were statistically significant. These findings indicate an in vivo polyclonal B-cell activation in Crohn's disease patients, possibly due to antigen(s) or infectious agent(s). In vitro experiments were performed with separated lymphocytes in order to characterise the mechanism responsible for the altered immune reactivity in Crohn's disease. These revealed an intrinsic B-cell defect as well as an impaired T-helper cell capacity in patients with Crohn's disease. Findings supporting the hypothesis of an increased suppressor activity in Crohn's disease patients could not be observed, and marker analyses revealed normal proportions with the exception of raised Leu 7 positive cells that mediate 'natural killer' and 'killer' cytolysis. We conclude that immune dysfunction in peripheral blood lymphocytes of Crohn's disease patients involves B-cells as well as T-helper cells.

The finding of various abnormalities of the immune response in patients with Crohn's disease has led to the concept that immune mechanisms are involved in the pathogenesis of this disease. ${ }^{1}$ Both humoral ${ }^{2-4}$ and cell-mediated ${ }^{4-7}$ reactivity to several gut- and bacteria-derived antigens have been shown in patients with Crohn's disease. Moreover, complex immunoregulatory influences are involved in immune reactions, and disturbances of immunoregulation have been found to be associated with many diseases in which immune mechanisms may be important. ${ }^{8}$

Controversial results have been obtained from experiments with peripheral blood mononuclear cells from patients with Crohn's disease: Hodgson ${ }^{9}$ reported a defective suppressor cell function, whereas Elson et al ${ }^{10}$ found a covert suppressor cell activity and Holdstock $e t$ al $^{11}$ a normal suppressor cell activity. On the other hand, intestinal lymphocytes have been reported to show

Address for correspondence: Dr G Sieber, Universitätsklinikum Steglitz, Hindenburgdam 30, D1000 Berlin 45, FRG.

Received for publication 10 February 1984 enhanced $^{12}$ or reduced $^{13}$ suppressor-cell activity. Similarly conflicting results were obtained when the proportions of circulating $\mathrm{T}$ - and B-lymphocytes were studied. $^{14-18}$

In view of these divergent findings, the present study was performed with the aim of investigating peripheral blood lymphocyte function in a series of Crohn's disease patients by means of a reverse haemolytic plaque.assay. We measured spontaneous immunoglobulin secreting cells, reflecting in vivo conditions, as well as pokeweed-mitogen-induced immunoglobulin secreting cells, reflecting the transforming capacity of resting B-cells. ${ }^{19}$ To define immunoregulatory influences of $\mathrm{T}$-helper and $\mathrm{T}$ suppressor cells, coculture experiments were done with isolated $\mathrm{T}$ - and B-cell populations obtained from normal individuals and patients with Crohn's disease.

\section{Methods}

SUBJECTS 1255 
37 years) with Crohn's disease were studied. The diagnosis of Crohn's disease was based on characteristic clinical, endoscopic, radiological, and histological features. The extent of the disease was determined by radiological and/or colonoscopic findings. Fifteen patients had colonic involvement; 12 had small bowel disease and 12 had small bowel and colonic involvement. At the time of investigation, 10 patients had active disease with Crohn's disease activity index (CDAI) ${ }^{20}$ higher than 150 (186-380, median 320); six were untreated, and four were treated with prednisolone and sulphasalazine for a short period of one to four days. Twenty nine patients had inactive disease (CDAI <150), and all of them were untreated for at least five months except for sulphasalazine in those patients with colonic involvement. Thirty five healthy control subjects were also studied. Their average age was 32 years (19 women, 16 men). All blood samples were obtained between 8.00 and 10.00 am and studied on the same day.

\section{CELL SUSPENSIONS}

Heparinised blood was taken, and peripheral blood mononuclear cells were obtained by Ficoll-Hypaque gradient centrifugation. In some experiments, Tand B-cell-enriched lymphocyte suspensions were purified by E-rosette separation as described. ${ }^{21}$

\section{MONOCLONAL ANTIBODY ANALYSIS OF}

PERIPHERAL LYMPHOCYTES

Seven monoclonal antibodies previously described by others were used. Briefly, OKT 3 binds to all mature T-cells and BA 1 to the whole B-cell subset. Regulatory T-helper/inducer and T-cytotoxic/ suppressor cells are restricted among OKT 4 positive and OKT 8 positive cells, respectively. OKM 1 identifies an antigen expressed on myelomonocytic lineage, whereas OKIa 1 recognises Ia-like antigens, and Leu 7 identifies cells that mediate 'natural killer' and 'killer' cytolysis.

To determine the frequency of positive cells, peripheral blood lymphocytes $\left(2 \times 10^{6}\right.$ cells $)$ were incubated with the appropriate concentrations of each monoclonal antibody for 30 minutes at $4^{\circ} \mathrm{C}$ in phosphate-buffered saline, washed and counterlabelled with an FITC-conjugated $F\left(a b^{\prime}\right)$ fragment of goat anti-mouse $\operatorname{IgG}$, washed again and then examined with a Zeiss ultraviolet microscope equipped with a vertical illuminator as described. ${ }^{22}$

\section{CULTURE CONDITIONS}

Cells were suspended in RPMI 1640 medium (Seromed, Germany) supplemented with $10 \%$ heat inactivated fetal calf serum (Gibco Lab, USA),
L-glutamine and antibiotics. The cells were cultured in $16 \times 125 \mathrm{~mm}$ Falcon plastic tubes at a concentration of $1 \times 10^{6} \mathrm{cells} / \mathrm{ml}$ in a total volume of $3 \mathrm{ml}$. Pokeweed mitogen (Gibco Lab, USA) was added at a concentration of $5 \mu \mathrm{l} / \mathrm{ml}$ when cultures were first set up. The cells were harvested after six days of incubation $\left(5 \% \mathrm{CO}_{2}\right.$ in air, $\left.37^{\circ} \mathrm{C}\right)$. In coculture experiments, $1.5 \times 10^{6}$ cells from a healthy volunteer were incubated together with $1.5 \times 10^{6}$ cells from the patient. In experiments with separated $B$ and $T$ cells, cocultures were set up at a ratio of $20: 80$. In some experiments performed for defining suppressor activity of the patient's T-cells (after B/T separation), cocultures between normal B-cells, normal T-cells and patient's T-cells were set up at a ratio of 20:60:20. All cultures or cocultures were done in duplicate. Cell viability evaluated by trypan blue exclusion ranged between 84 and $98 \%$.

\section{REVERSE HAEMOLYTIC PLAQUE ASSAY}

The details of the reverse haemolytic plaque assay have been described previously. ${ }^{19}$ Briefly, proteinA-coupled sheep red blood cells were used as indicator cells and incubated in agar with cultured cells. After addition of a developer antiserum with specificity for $\alpha, \gamma$ and $\mu$ (Medac, Germany) and complement (Behring, Germany), the number of plaques was determined and expressed as the total number of plaques per $10^{6}$ lymphocytes (mean of duplicate determination). Controls were done in each experiment by omitting cells, complement, developer antiserum, or all three entities.

STATISTICAL ANALYSIS

Results were compared using the Wilcoxon's test.

\section{Results}

SPONTANEOUS IMMUNOGLOBULIN SECRETING CELLS IN PATIENTS WITH CROHN'S DISEASE

Spontaneous immunoglobulin secreting cells were estimated immediately after cell separation using the reverse haemolytic plaque assay. As shown in Figure 1, patients with active Crohn's disease (CDAI >150) showed a significant increase in spontaneous immunoglobulin secreting cells compared with normal individuals as well as Crohn's disease patients with inactive disease (2934 vs $313 v s$ 554). In patients with inactive Crohn's disease, we also found an increase in spontaneous immunoglobulin secreting cells, which was not statistically significant. In active Crohn's disease, there was no difference between patients with short term treatment and untreated patients. 


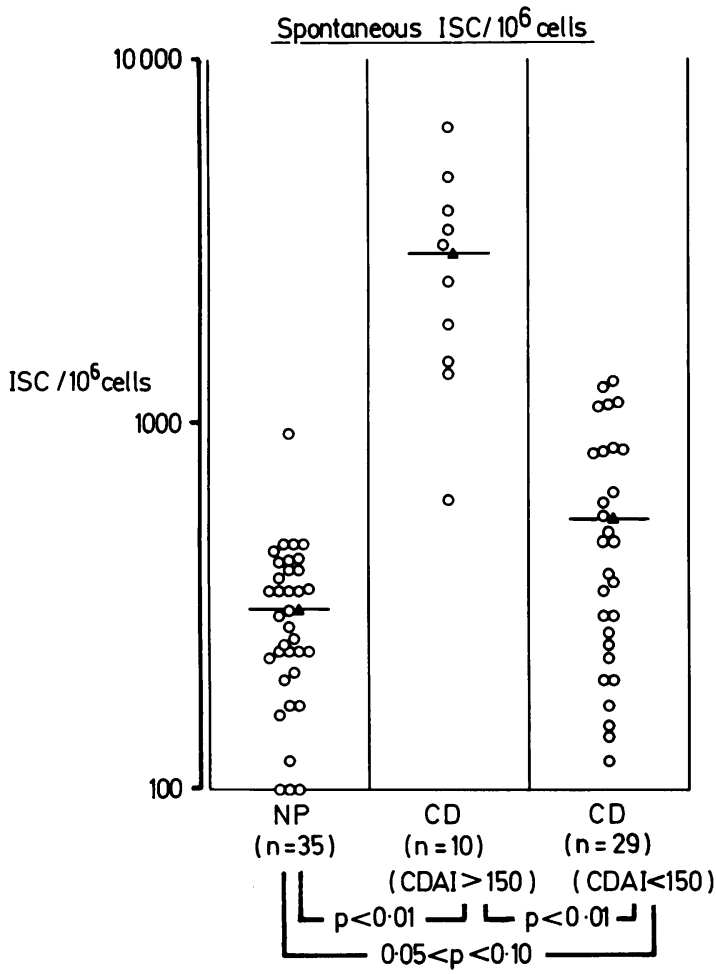

Fig. 1 Estimation of spontaneous immunoglobulinsecreting cells (ISC) in peripheral blood lymphocytes from normal persons (NP), patients with active Crohn's disease $(C D A I>150)$ and patients with inactive Crohn's disease $(C D A I<150)$.

POKEWEED-MITOGEN-INDUCED IMMUNOGLOBULIN SECRETING CELLS IN PATIENTS WITH CROHN'S DISEASE

When peripheral blood mononuclear cells were stimulated with pokeweed-mitogen over a period of six days, the number of immunoglobulin secreting cells was found to show a statistically significant reduction in patients with either active or inactive disease as compared with normal individuals (903 vs 3241 vs 18 934). Moreover, there was also a statistically significant difference in the reactivity between active and inactive Crohn's disease. The overall results are depicted in Figure 2. In active Crohn's disease, there was no difference between patients with short-term treatment and untreated patients.

COCULTURES BETWEEN PERIPHERAL BLOOD MONONUCLEAR CELLS FROM CROHN'S DISEASE PATIENTS AND NORMAL INDIVIDUALS Crohn's disease patients' lymphocytes were cultured together with lymphocytes from normal donors at a

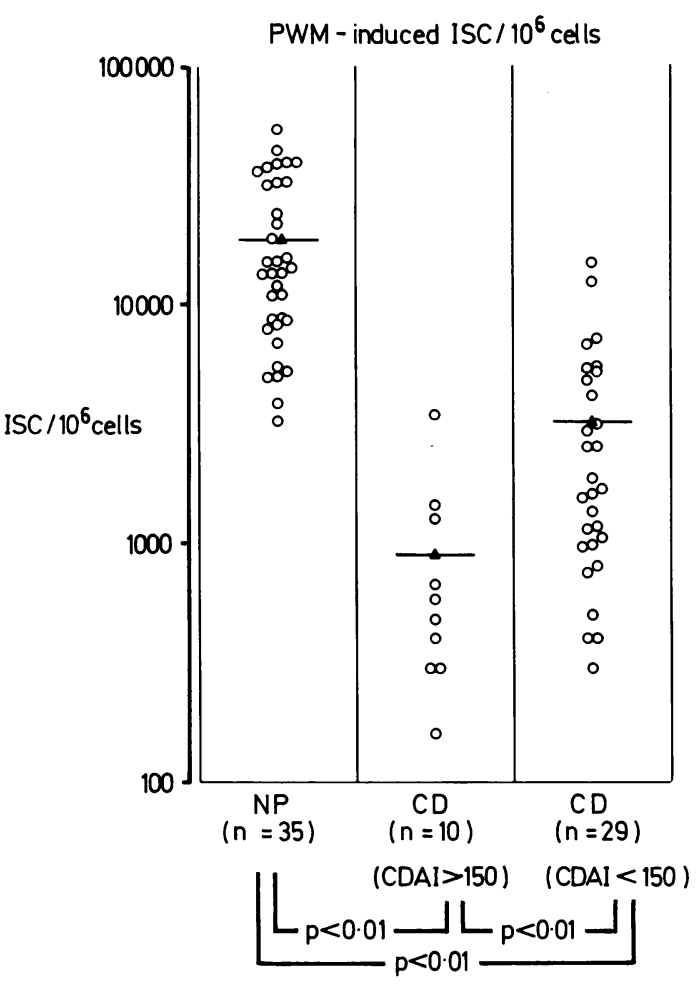

Fig. 2 Estimation of pokeweed-mitogen-induced immunoglobulin-secreting cells (ISC) in peripheral blood lymphocytes from normal persons (NP), patients with active Crohn's disease $(C D A I>150)$ and patients with inactive Crohn's disease $(C D A I<150)$.

ratio of $1: 1$. Such coculture experiments are useful tools to elucidate increased suppressor or helper activity, as the responses of peripheral blood mononuclear cells from two HLA-non-identical individuals in coculture are additive - that is, not influenced by HLA diversity. ${ }^{19}$ Thus, cocultures between peripheral blood mononuclear cells from normal individuals and patients with active $(n=5)$ or inactive $(n=9)$ Crohn's disease always lead to responses within the predicted (calculable) range.

\section{EXPERIMENTS WITH SEPARATED LYMPHOCYTE} SUBPOPULATIONS

In order to investigate the cellular mechanism responsible for impaired immunoglobulin secreting cells generation in patients with Crohn's disease, experiments were done in which E-rosetteseparated lymphocyte subpopulations from normal individuals were cocultured with those from patients with Crohn's disease at a B:T ratio of $20: 80$. The results shown in Table 1 show a clear intrinsic B-cell 
Table 1 Pokeweed mitogen (PWM)-induced generation of immunoglobulin-secreting cells (ISC) in co-culture of lymphocyte subpopulations from normal individuals and patients with Crohn's disease (CD)

\begin{tabular}{|c|c|c|c|c|c|c|c|c|}
\hline \multirow[b]{2}{*}{$\begin{array}{r}\text { Experiment number } \\
C D A I\end{array}$} & \multicolumn{8}{|c|}{$I S C / 10^{6}$ cells } \\
\hline & $l_{>150}$ & $\stackrel{I I}{>150}$ & $\begin{array}{l}I I I \\
>150\end{array}$ & $\begin{array}{l}I V \\
<150\end{array}$ & $\begin{array}{l}V \\
<150\end{array}$ & $\begin{array}{l}V I \\
<150\end{array}$ & $\begin{array}{l}V I I \\
<150\end{array}$ & $\begin{array}{l}V I I I \\
<150\end{array}$ \\
\hline \multicolumn{9}{|l|}{ Unseparated lymphocytes } \\
\hline Normal & 14400 & 6400 & 13500 & 5600 & 13500 & 15200 & 12000 & 12000 \\
\hline Patient & 560 & 320 & 200 & 4700 & 100 & 1000 & 100 & 400 \\
\hline \multicolumn{9}{|l|}{ Separated lymphocytes } \\
\hline$B_{N} \times T_{N}(20: 80)$ & 14000 & 7800 & 11200 & 5300 & 11500 & 12500 & 9500 & 9500 \\
\hline $\mathrm{B}_{\mathrm{CD}} \times \mathrm{T}_{\mathrm{CD}}(20: 80)$ & 840 & 160 & 900 & 4000 & 100 & 300 & 0 & 300 \\
\hline $\mathrm{B}_{\mathrm{CD}} \times \mathrm{T}_{\mathrm{N}}(20: 80)$ & 320 & 110 & 200 & 5900 & 100 & 300 & 300 & 200 \\
\hline$B_{N} \times T_{C D}(20: 80)$ & 2860 & 240 & 11000 & 4600 & 7200 & 1000 & 2000 & 3800 \\
\hline $\mathrm{B}_{\mathrm{N}} \times \mathrm{T}_{\mathrm{N}} \times \mathrm{T}_{\mathrm{CD}}(20: 60: 20)$ & 14860 & 6900 & nd & 9900 & 11950 & nd & 10800 & nd \\
\hline
\end{tabular}

$T$ and $B$ lymphocyte subpopulations were purified by E-rosette separation and cocultured at different ratios. The isolated $T$ and $B$ fractions alone did not respond to PWM. CDAI = Crohn's disease activity index; $\mathrm{B}=$ separated $\mathrm{B}$-cells; $\mathrm{T}$ = separated T-cells;

$\mathrm{N}=$ normal individual $\mathbf{C D}=$ patient with $\mathrm{CD} ; \mathrm{nd}=$ not done.

defect in almost all patients with Crohn's disease in the pokeweed-mitogen-driven system. Moreover, there was a defective T-helper cell capacity in most experiments, as shown in coculture experiments between normal B-cells and patients' T-cells. As in the coculture experiments with unseparated peripheral blood mononuclear cells, an increased suppressor cell activity could never be observed when isolated normal B-cells, normal T-cells and patients' T-cells were cocultured at a ratio of 20:60:20 (see Table 1). In two experiments, the proportion of patients' T-cells was even increased up to $50 \%$ (ratio 20:30:50), which did not influence B-cell reactivity. Likewise, no suppressor activity could be shown when patients' T-cells were cocultured with unseparated lymphocytes from normal individuals at a ratio of 50:50.

\section{MARKER ANALYSES}

Results of monoclonal antibody studies on peripheral blood lymphocytes from 12 patients with Crohn's disease compared with 50 healthy age- and sex-matched subjects are listed in Table 2 . Four of the patients were in an active and eight in an inactive disease state. Because both groups showed similar values, they are depicted together. Except for data obtained from Leu 7 studies, no statistically significant differences were seen in lymphocyte subpopulations when they were compared with those from a group of normal individuals. Relative numbers of Leu 7 positive cells mediating 'natural killer' and 'killer"' cytolysis, however, were increased in the Crohn's disease group $(17 \cdot 5 \pm 4 \cdot 1 \mathrm{vs}$ $9.9 \pm 6.3$ in normal subjects, $p<0.01)$.

\section{Discussion}

Immunological investigations in patients with Crohn's disease have revealed a number of phenotypic and functional abnormalities that might be involved in the initiation or perpetuation of this disease.

Previous functional studies using peripheral blood lymphocytes from Crohn's disease patients have suggested such contradictory findings as reduced spontaneous and/or concanavalin-A-induced

Table 2 Percentage of peripheral blood lymphocytes determined by E-rosette formation or by monoclonal antibody analysis

\begin{tabular}{|c|c|c|c|c|c|c|c|c|}
\hline & $E-R o s$ & $O K T 3$ & $O K T 4$ & $O K T 8$ & $O K M I$ & OKIa 1 & Leu 7 & $B A I$ \\
\hline $\begin{array}{l}\text { Normal individuals } \\
\quad(n=50) \\
\text { Crohn's disease patients } \\
\quad(n=12)\end{array}$ & $\begin{array}{l}66 \cdot 4^{*} \\
\pm 7 \cdot 0 \\
62 \cdot 6 \\
\pm 2 \cdot 0\end{array}$ & $\begin{array}{l}66 \cdot 7 \\
\pm 4 \cdot 0 \\
64 \cdot 2 \\
\pm 3 \cdot 4\end{array}$ & $\begin{array}{l}40 \cdot 1 \\
\pm 3 \cdot 1 \\
38 \cdot 5 \\
\pm 2 \cdot 4\end{array}$ & $\begin{array}{l}19 \cdot 2 \\
\pm 2 \cdot 9 \\
20 \cdot 2 \\
\pm 4 \cdot 5\end{array}$ & $\begin{array}{l}16 \cdot 3 \\
\pm 4 \cdot 9 \\
14 \cdot 2 \\
\pm 2 \cdot 6\end{array}$ & $\begin{array}{l}14 \cdot 4 \\
\pm 4 \cdot 6 \\
15 \cdot 0 \\
\pm 2 \cdot 0\end{array}$ & $\begin{array}{l}9 \cdot 9 \\
\pm 6 \cdot 3 \\
17 \cdot 5 \\
\pm 4 \cdot 1\end{array}$ & $\begin{array}{l}9 \cdot 7 \\
\pm 6 \cdot 4 \\
12 \cdot 0 \\
\pm 3 \cdot 6\end{array}$ \\
\hline p & ns & ns & ns & ns & ns & ns & $<0.01$ & ns \\
\hline
\end{tabular}

* Mean values \pm 1 SEM (standard error of the mean); ns = not significant. E-Ros = sheep erythrocyte rosette-forming cells. The reactivity pattern of the monoclonal antibodies is described in Methods. 
suppressor activity, ${ }^{9}$ 23-25 normal suppressor activity $^{11}$ or even increased suppressor activity. ${ }^{10} 26$ Similarly discrepant results have been revealed at the mucosal level: increased suppressor activity, ${ }^{12}$ normal suppressor activity ${ }^{27}$ or reduced suppressor activity. ${ }^{13}$ No information is available on T-helper cell function in peripheral blood lymphocytes of Crohn's disease patients, as, in the experiments of Elson et al, a covert suppressor activity manifested after the T/B-cell separation procedure ${ }^{10}$ could have masked a possibly normal $\mathrm{T}$-helper cell function.

Characterisation of peripheral blood lymphocytes and T-lymphocyte subpopulations in Crohn's disease patients with conventional or monoclonal markers revealed the following briefly summarised results: normal absolute T-cell number, ${ }^{28}$ decreased absolute T-cell numbers, ${ }^{17} 29$ normal proportion of T-cell subsets, ${ }^{14-17} 30$ reduced $\mathrm{T}(\gamma)$ and/or $\mathrm{T}(\mu)$ positive subsets; $;^{18} 2431$ peripheral blood $\mathrm{B}$ lymphocytes were reported to be reduced, ${ }^{32}$ normal $^{16}$ or increased. ${ }^{29}$ At the mucosal level, Re Mine et al described decreased $\mathrm{T}(\gamma)$ subpopulations, ${ }^{33}$ and Brandtzaeg and Baklien reported increased numbers of IgG positive cells and decreased numbers of $\operatorname{IgA}$ positive cells. ${ }^{34}$

After this confusing enumeration of contradictory data, it is necessary to state that lymphocyte functions evaluated in different assay systems can yield different results. Therefore it is not acceptable to generalise from the results obtained in a specific assay system.

For better characterisation of B cell as well as T-helper and T-suppressor cell abnormalities in one defined assay system corresponding as closely as possible to the in vivo situation, we used a reverse haemolytic plaque assay which enabled us to measure the following parameters: (1) Spontaneous immunoglobulin secreting cell numbers reflecting the in vivo situation, in which B-cells can transform into immunoglobulin secreting cells under the influence of T-helper and T-suppressor cells. (2) Pokeweed-mitogen-induced immunoglobulin secretion indicating the capacity of B-cells to differentiate into immunoglobulin secreting cells under the influence of T-helper and T-suppressor cells in vitro after stimulation with the polyclonal B-cell activator pokeweed-mitogen. (3) Function of B-cells as well as T-helper and T-suppressor cells in vitro after B/T-cell separation and reconstitution with autologous or allogeneic cells followed by stimulation with pokeweed-mitogen.

The most exciting finding of the present study was a marked significant increase of spontaneous immunoglobulin secreting cells in patients with active Crohn's disease (approximately $10 \times$ normal values) and, to a lesser extent, in patients with inactive Crohn's disease (approximately $2 \times$ normal values) (Fig. 1). Correspondingly, there was a significant inability of peripheral blood lymphocytes from both active and inactive Crohn's disease patients to differentiate into immunoglobulin secreting cells after stimulation with pokeweedmitogen in vitro (Fig. 2). These findings are consistent with a marked degree of polyclonal B-cell activation in vivo and agree on the whole with the results of Holdstock et $a^{26}$ and Macdermott $e t a l^{35}$ who estimated IgA, IgM and IgG secreted during a cultivation period of seven or 12 days in cell culture supernatants using an ELISA or a radioimmunoassay respectively. Such polyclonal B-cell activation in vivo may-among other possibilities - for example, antigen stimulation - be suggestive of viral stimulation or transformation and has been reported during infection with some herpes viruses, most notably the Epstein-Barr virus. ${ }^{36}$ Other disease states in which polyclonal B-cell activation has been demonstrated is the acquired immunodeficiency syndrome ${ }^{37}$ and certain connective tissue diseases. ${ }^{38}$

To explain the phenomenon of polyclonal B-cell activation on a cellular basis, three abnormalities have been proposed: (1) excessive T-cell help, (2) decreased T-cell suppression, or (3) direct B-cell activation. To discriminate between these possibilities, coculture experiments were performed: unseparated, pokeweed-mitogen-stimulated lymphocytes from a normal individual and a patient with active or inactive Crohn's disease were cocultured. These pilot experiments revealed no evidence for an altered function of T-suppressor cells in Crohn's disease patients. Furthermore, in experiments with separated T- and B-cells from normal individuals and Crohn's disease patients, evidence of an intrinsic B-cell defect as well as a defective T-helper cell capacity was manifest in almost all patients. Defective helper cell capacity in Crohn's disease patients was easily demonstrable in coculture experiments between normal B-cells and patients' T-cells (Table 1). On the other hand, normal T-cells could not help patients' B-cells to differentiate into immunoglobulin secreting cells (Table 1), and patients' T-cells did not exert abnormal suppressor activity, even in various coculture experiments between normal B-cells, normal T-cells and patients' T-cells (Table 1). Therefore, we would postulate an intrinsic B-cell defect defined by the pokeweed-mitogen-driven system in almost all Crohn's disease patients, whereas Elson et al interpreted the inability of patients' B-cells to differentiate as a consequence of suppressor activity. ${ }^{10}$ Because the suppressor activity in the experiments of Elson et al ${ }^{10}$ was not dependent on the technique used for $T$-cell 
separation, this discrepancy could only be explained by the different effector systems or culture conditions. Elson et al, ${ }^{10}$ using a radioimmunoassay, measured supernatant IgM produced during the whole culture period of seven days; whereas, in the present study, immunoglobulin secreting cells were estimated after a culture of six days. Finally, these experimental differences might also explain the finding of Holdstock et $a l,{ }^{26}$ who reported increased activity of a prostaglandin-dependent suppressor system in peripheral blood mononuclear cells of patients with inflammatory bowel disease.

In general, our findings make the assumption of excessive T-cell help or defective T-cell suppression in Crohn's disease patients seem unlikely. This conclusion is also supported by numerous marker analyses $^{14-17} 30$ including the present one (Table 2). Therefore we would favour the hypothesis of a direct polyclonal B-cell activation in patients with Crohn's disease, which is substantiated by the observation that the extent of polyclonal B-cell activation was not affected by short-term treatment (one to four days) in four patients with active disease. Thus, one might speculate that polyclonal activation, possibily due to an infectious agent(s), may initiate or perpetuate an autoimmune process leading to the presence of circulating antibodies to bowel epithelial cells. ${ }^{39}$

An unresolved problem is whether the abnormal immune reactivity in the peripheral blood is relevant to the pathogenesis of the intestinal inflammatory process or only a concomitant phenomenon. As it is difficult to obtain well defined intestinal lymphocyte populations, there are very few and contradictory observations in humans, as previously mentioned. Nevertheless, direct access to the intestinal lymphoid system is a prerequisite for better interpretation of immunologic abnormalities in Crohn's disease. Further elucidation of both local and systemic alterations of immune functions in Crohn's disease may provide new insights into the pathogenesis of this disease, thus leading to new approaches in therapy.

This work was supported by the Deutsche Forschungsgemeinschaft $(\mathrm{Ru} 215 / 2)$. We wish to thank Gudrun Bochert for excellent technical assistance.

\section{References}

1 Thayer WR. Inflammatory bowel disease. Where are the frontiers? Med Clin N Am 1980; 64: 1221-31.

2 Kraft SC, Kirsner JB. The immunology of ulcerative colitis and Crohn's disease: clinical and humoral aspects. In: Kirsner JB, Shorter RG, eds. Inflammatory bowel disease. Philadelphia: Lea \& Febiger, 1975: 60-80.

3 Thomas HC, Jewel DP. Clinical gastrointestinal immunology. Oxford: Blackwell Scientific Publications, 1979: 121-63.

4 Das DM, Dubin R, Nagai T. Isolation and characterisation of colonic tissue bound antibodies from patients with idiopathic ulcerative colitis. Proc Natl Acad Sci USA 1978; 75: 4528-32.

5 Bartnik W, Swarbrick ET, William SC. A study of peripheral leucocyte migration in agarose-medium in inflammatory bowel disease. Gut 1974; 15: 294-300.

6 Bendixen G. Cellular hypersensitivity to components of intestinal mucosa in ulcerative colitis and Crohn's disease. Gut 1969; 10: 631-6.

7 Bull DM, Ignaczak TF. Enterobacterial common antigen-induced lymphocyte reactivity in inflammatory bowel disease. Gastroenterology 1973; 64: 43-50.

8 Waldmann TA (moderator). Disorders of suppressor immuno-regulatory cells in the pathogenesis of immunodeficiency and autoimmunity. Ann Intern Med 1980; 88: 1221-31.

9 Hodgson HJF, Wands JR, Isselbacher KJ. Decreased suppressor cell activity in inflammatory bowel disease. Clin Exp Immunol 1978; 32: 451-8.

10 Elson CO, Braeff AS, James SP, Strober W. Covert suppressor T cells in Crohn's disease. Gastroenterology 1981; 80: 1513-21.

11 Holdstock G, Chastenay BF, Krawitt EL. Functional suppressor T cell activity in Crohn's disease and the effects of sulphasalazine. Clin Exp Immunol 1982; 48: 619-24.

12 Fiocchi C, Youngman KR, Farmer RG. Immunoregulatory function of human intestinal mucosa lymphoid cells: Evidence for enhanced suppressor cell activity in inflammatory bowel disease. Gut 1983; 24: 692-701.

13 Goodacre RL, Bienenstock J. Reduced suppressor cell activity in intestinal lymphocytes from patients with Crohn's disease. Gastroenterology 1982; 82: 653-8.

14 Makiyama K, Selby WS, Jewell DP. E rosetting lymphocytes in inflammatory bowel disease. An analysis using monoclonal antibody. Clin Exp Immunol 1983; 52: 350-4.

15 Pfreundschuh M, Feurle GE, Springer A, Gause A, Beck JD. T-lymphocyte subpopulations in the peripheral blood of patients with Crohn's disease. Scand J Gastroenterol 1981; 16: 845-51.

16 Roche JK, Watkins MH, Cook SL. Inflammatory bowel disease: Prevalence and level of activation of circulating T-lymphocyte subpopulations mediating suppressor/cytotoxic and helper function as defined by monoclonal antibodies. Clin Immunol Immunopathol 1981; 25: 362-73.

17 Selby WS, Jewell DP. T lymphocyte subsets in inflammatory bowel disease: peripheral blood. Gut 1983; 24: 99-105.

18 Victorino RMM, Hodgson HJF. Alteration in T lymphocyte subpopulations in inflammatory bowel disease. Clin Exp Immunol 1980; 41: 156-65. 
19 Sieber G, Bochert G, Enders B, Rühl H. Characteristics of immunoglobulin secretion in man evaluated by a reverse hemolytic plaque assay. Blut 1980; 41: 81-92.

20 Best WR, Becktel JM, Singleton JW, Kern F. Development of a Crohn's disease activity index. National cooperative Crohn's disease study. Gastroenterology 1976; 70: 439-44.

21 Rühl H, Scholle H, Bochert G, Vogt W. Activation of lymphocyte subpopulations in patients with chronic lymphocytic leukemia. Z Immunol Forsch 1978; 154: 75-87.

22 Herrmann F, Lochner A, Philippen H, Jauer B, Rühl $H$. Imbalance of $T$ cell subpopulations in patients with chronic lymphocytic leukemia of the B-cell type. Clin Exp Immunol 1982; 49: 157-62.

23 Victorino RMM, Hodgson HJF. Spontaneous suppressor cell function in inflammatory bowel disease. Dig Dis Sci 1981; 26: 801-6.

24 Shorter RG. $T_{G}$ cells and non-specific concanavalin-Ainduced suppressor cell activity in vitro in colonic inflammatory bowel disease and in colorectal carcinoma. In: Pena AS, Weterman IT, Booth CC, Strober W, eds. Recent advances in Crohn's disease. The Hague: Martinus-Nijhoff, 1981: 448-58.

25 Knapp W, Smolen JS, Lanzer G et al. Con-A induced suppressor cell activity in IBD and other inflammatory conditions. In: Pena AS, Weterman IT, Booth CC, Strober W, eds. Recent advances in Crohn's disease. The Hague: Martinus-Nijhoff, 1981: 380-8.

26 Holdstock G, Ershler WB, Krawitt EL. Defective lymphocyte $\operatorname{IgA}$ production in inflammatory bowel disease. Clin Immunol Immunopathol 1982; 24: 47-54.

27 Fiocchi C, Battisto JR, Farmer RG. Gut mucosal lymphocytes in inflammatory bowel disease. Isolation and preliminary functional characterization. Dig Dis Sci 1979; 24: 705-17.

28 Bird AG, Britton S. No evidence for decreased lymphocyte reactivity in Crohn's disease. Gastroenterology 1974; 67: 926-32.

29 Strickland RG, Korsmeyer S, Soltis RD, Wilson ID, Williams RC Jr. Peripheral blood $\mathrm{T}$ and $\mathrm{B}$ cells in chronic inflammatory bowel disease. Gastroenterology 1974; 67: 569-77.

30 Brown TE, Bankhurst AD, Strickland RG. Natural killer cell function and lymphocyte subpopulation profiles in inflammatory bowel disease. J Clin Lab Immunol 1983; 11: 113-7.

31 Pena AS, Cnossen J, Damsteeg MG et al. T cell subpopulations in Crohn's disease. In: Pena AS, Weterman IT, Booth CC, Strober W, eds. Recent advances in Crohn's disease. The Hague: MartinusNijhoff, 1981: 403-6.

32 Auer IO, Götz S, Ziemer E, Malchow H, Ehms H. Immune status in Crohn's disease. II. Peripheral blood B lymphocytes enumerated by means of $\mathrm{F}\left(\mathrm{Ab}^{\prime}\right)_{2}$ antibody fragments, null and T lymphocytes. Gut 1979; 20: $261-8$.

33 Re Mine SG, Bartnik W, Bahn RC, Shorter RG. Further characterization of lymphocytes from human colonic lamina propria: identification of $\mathrm{T}_{\mathrm{G}}$ cells. Clin Exp Immunol 1981; 46: 294-300.

34 Brandtzaeg $\mathrm{P}$, Baklien $\mathrm{K}$. Immunohistochemical studies of the formation and epithelial transport of immunoglobulins in normal and diseased human intestinal mucosa. Scand J Gastroenterol 1976; 11: suppl 36: 1-45.

35 Macdermott RP, Nash GS, Bertovich MJ, Seiden MV, Bragdon MJ, Beale MG. Alterations of $\operatorname{IgM}$, IgG, and IgA synthesis and secretion by peripheral and intestinal mononuclear cells from patients with ulcerative colitis and Crohn's disease. Gastroenterology 1981; 81: 844 52.

36 van Furth R, Schuit HRE, Hijmans W. The formation of immunoglobulins by human tissues in vitro. IV. Circulating lymphocytes in normal and pathological conditions. Immunology 1966; 11: 29-40.

37 Lane HC, Masur H, Edgar LC, Whalen G, Rook AH, Fauci AS. Abnormalities of B-cell activation and immunoregulation in patients with the acquired immunodeficiency syndrome. N Engl J Med 1983; 309: 453-8.

38 Budman DR, Merchant EB, Steinberg AD. Increased spontaneous activity of antibody forming cells in the peripheral blood of patients with active SLE. Arthritis Rheum 1977; 20: 829-33.

39 Lagercrantz R, Hammarström S, Perlmann P, Gustafson BE. Immunological studies in ulcerative colitis. II. Incidence of antibodies to colon antigen in ulcerative colitis and other gastrointestinal diseases. Clin Exp Immunol 1966; 1: 263-76. 